\title{
Effect of Urucu oil (Brazilian Amazon) on the biomass of the aquatic macrophyte Eichbornia crassipes (Mart.) Solms (Pontederiaceae)
}

\author{
Efeito do petróleo de Urucu (Amazônia/Brasil) sobre a biomassa da \\ macrófita aquática Eichhornia crassipes (Mart.) Solms (Pontederiaceae)
}

Luciana Carvalho Crema ${ }^{1}$, Jose Francisco Vicente Biudes ${ }^{2,3}$ and

\section{Antonio Fernando Monteiro Camargo ${ }^{2,3}$}

${ }^{1}$ Instituto Chico Mendes de Conservação da Biodiversidade,

Centro Nacional de Pesquisa e Conservação da Biodiversidade Amazônica, Manaus, AM, Brazil e-mail: luciana.crema@icmbio.gov.br

${ }^{2}$ Departamento de Ecologia, Instituto de Biociências, Universidade Estadual Paulista - UNESP,

Av. 24-A, 1515, Bela Vista, CEP 13506-900, Rio Claro, SP, Brazil

e-mail: jfvbiudes@gmail.com; afmc@rc.unesp.br

${ }^{3}$ Centro de Aquicultura, Universidade Estadual Paulista - UNESP,

Via de Acesso Professor Paulo Donato Castellane, s/n, CEP 14884-900, Jaboticabal, SP, Brazil

\begin{abstract}
The rivers and floodplain lakes of the Urucu petroleum-bearing region in central Amazonia are extensively colonized by aquatic macrophytes, which may be affected by accidental spills during oil extraction and transportation operations. Among the species of macrophytes, the free-floating Eichhornia crassipes (water hyacinth) is abundant; Aim: The objective of this study was to evaluate the effect of different dosages of Urucu crude oil $\left(0,0.5,1.5\right.$ and $\left.3.0 \mathrm{~L} . \mathrm{m}^{-2}\right)$ on the biomass of E. crassipes and on some physical and chemical characteristics of the water in which the plant grew; Methods: The experiment was conducted over a period of 84 days. Every seven days, the biomass (live and dead) of $E$. crassipes and the temperature, $\mathrm{pH}$, electrical conductivity and dissolved oxygen in the water were measured; Results: The dosage of $0.5 \mathrm{~L} \cdot \mathrm{m}^{-2}$ was sufficient to cause partial mortality (48\%) in E. crassipes after 35 days of exposure to oil. The dosage of $3.0 \mathrm{~L} . \mathrm{m}^{-2}$ caused total mortality $(100 \%)$ in E. crassipes after 84 days of exposure. The decomposition of the oil and the dead biomass of $E$. crassipes reduced the dissolved oxygen and $\mathrm{pH}$, and increased electrical conductivity and concentrations of total phosphorus in the water; Conclusions: We conclude that an oil spill can cause total mortality in the local population of one macrophyte species, but not of another. This may alter the macrophyte species diversity in the impacted region. In the case of E. crassipes and Pistia stratiotes, an Urucu crude oil spill could favor $E$. crassipes, the species less sensitive to oil.
\end{abstract}

Keywords: water, water hyacinth, biomass, dosage, mortality.

Resumo: Os rios e lagos de várzea da província petrolífera de Urucu, na Amazônia Central, são amplamente colonizados por macrófitas aquáticas, que podem ser afetadas por acidentes durante a exploraçáo e o transporte de petróleo. Entre as macrófitas, a espécie flutuante Eichhornia crassipes (aguapé) ocorre abundantemente na região; Objetivo: $\mathrm{O}$ objetivo desse estudo foi verificar o efeito de diferentes dosagens do petróleo de Urucu $\left(0 ; 0,5 ; 1,5\right.$ e 3,0 L.m $\left.{ }^{-2}\right)$ na biomassa viva e morta de $E$. crassipes e em algumas características físicas e químicas da água; Métodos: $\mathrm{O}$ experimento teve oitenta e quatro dias de duraçáo. A cada sete dias foi determinada a biomassa (viva e morta) de E. crassipes e os valores de temperatura, $\mathrm{pH}$, condutividade elétrica e oxigênio dissolvido da água; Resultados: A dosagem de $0,5 \mathrm{~L} \cdot \mathrm{m}^{-2}$ foi suficiente para causar mortalidade parcial (48\%) em $E$. crassipes após trinta e cinco dias de exposição ao petróleo. A dosagem de 3,0 L.m ${ }^{-2}$ causou mortalidade total (100\%) em E. crassipes em oitenta e quatro dias de exposição. A decomposiçáo do petróleo e da biomassa morta de E. crassipes provocam a redução do oxigênio dissolvido e do $\mathrm{pH}$, e aumento da condutividade elétrica e de fósforo total na água; Conclusóes: Nós concluímos que um derramamento de petróleo pode provocar mortalidade total em uma população de uma espécie de macrófita, mas não em uma outra. Isto pode alterar a diversidade de espécies de macrófitas na região impactada. No caso de Eichhornia crassipes e Pistia stratiotes, um derramamento de petróleo de Urucu pode favorecer $E$. crassipes, a espécie menos sensível ao petróleo.

Palavras-chave: água, aguapé, biomassa, dosagem, mortalidade. 


\section{Introduction}

In the Urucu region of the Brazilian Amazon, intense exploitation and transportation of oil and natural gas are continuing. The Urucu field produces 50 thousand barrels of oil and 10.36 thousand cubic meters of natural gas per day (Petrobrás, 2010). This production generates a risk of accidental spills, which could seriously impact rivers and floodplain lakes. The crude oil extracted from the Urucu field is classified as 'light', and according to Pezeshki and DeLaune (1993), this type of petroleum can be easily taken up by vegetation and cause immediate harm.

Aquatic macrophytes are an important community in shallow-water ecosystems, possessing a high rate of primary production, participating in nutrient recycling and providing food for herbivores and detritivores (Tundisi and Matsumura-Tundisi, 2008). Floodplain lakes of the Amazon region are rich in aquatic macrophytes, including the abundant free-floating water hyacinth Eichhornia crassipes (Mart.) Solms (Pontederiaceae) (Lopes et al., 2009). This species reproduces sexually and asexually, and can rapidly colonize new areas, forming dense banks where conditions are favorable (Villamagna and Murphy, 2010).

The impacts of an oil spill on the aquatic vegetation depend on diverse factors, including i) the characteristics of the oil, its type, degradation time and how its components alter over the period when it remains in contact with the vegetation; ii) the vegetation aspects, such as the species, the parts of the plants involved, the growth and phenological stages; and iii) the environmental conditions, such as sediment granulometry, season of the year, inundation level and climate characteristics (Lin and Mendelssohn, 1996; DeLaune et al., 2003).

The majority of studies on the effects of petroleum products on aquatic macrophytes have involved species of estuarine regions (Lin and Mendelssohn, 1996; Stepanyan and Voskoboinikov, 2006; Wernick et al., 2009), and similar studies of freshwater macrophytes are rare. In Brazil, Silva and Camargo (2007) showed that Pistia stratiotes $L$. (Araceae) is extremely sensitive to Urucu petroleum; low doses (0.1, 0.2 and 0.3 L. $\left.\mathrm{m}^{-2}\right)$ caused death in plants. The effect of Urucu oil on E. crassipes was evaluated by Lopes et al. (2009), who observed that exposure of this species to concentrations between 0.08 and $15.89 \mathrm{~L} \cdot \mathrm{m}^{-2}$ reduced the number and size of leaves. The objective of the current study was to evaluate the effects of different dosages of Urucu crude oil on the biomass of E. crassipes, through the determination of live and dead biomass of the whole plant. In addition, we evaluated the alterations in the physical and chemical characteristics of the water that were caused by the exposure of the macrophyte to oil.

\section{Material and Methods}

An experiment with four treatments and three replications was conducted over 84 days in the Experimental Garden of the Biosciences Institute (UNESP, Rio Claro) in the State of São Paulo, Brazil. Each treatment consisted of a different oil dosage: 0 (control), $0.5,1.5$ and $3.0 \mathrm{~L} \cdot \mathrm{m}^{-2}$. The oil dosage used in the treatments was based on other studies such as those of Pezeshki and DeLaune (1993), Pezeshki et al. (1998), Silva and Camargo (2007) and Lopes et al. (2009). The 12 experimental units consisted of plastic boxes $0.55 \times 0.35 \mathrm{~m}$ (a surface area of $0.1925 \mathrm{~m}^{-2}$ ) and $0.25 \mathrm{~m}$ deep; the boxes were filled initially with $630 \pm 17 \mathrm{~g}$ wet mass of E. crassipes per $\mathrm{m}^{2}\left(\mathrm{gWM} \cdot \mathrm{m}^{-2}\right)$. The size of the boxes and the mass of the macrophyte were used to simulate a nearshore area of a typical waterbody. The individuals of $E$. crassipes were collected in natural freshwater habitats in southern São Paulo State, Brazil, where the species is abundant. The Urucu crude oil was obtained from the Urucu Oil Province, through the Training Program of Human Resources in Petroleum Geology and Environmental Sciences Applied to Oil \& Gas and Biofuels (PRH-05) of Unesp/Rio Claro. The experimental units were initially filled with water, then $E$. crassipes was added, and finally the oil.

Every seven days, the temperature, $\mathrm{pH}$, electrical conductivity and dissolved oxygen were measured in the water of each experimental unit, using a Horiba U-10 multisensor. The water level of the boxes was also completed after the measurements. The total phosphorus (TP) (Golterman et al., 1978) and total Kjeldahl nitrogen (TKN) (MacKereth et al., 1978) concentrations in the water of each experimental unit were measured at the start and end of the experiment.

At weekly intervals, the live and dead biomass of E. crassipes was measured. We defined dead biomass as that with more than $50 \%$ colored brownish-yellow, and the tissues detached from the individual. Live biomass was removed from the experimental units, placed in sieves for approximately 5 minutes to drain excess water (Agami and Reddy, 1990), weighed (as $\mathrm{gWM}_{\mathrm{m}} \mathrm{m}^{-2}$ ), and returned to the respective experimental unit. Dead biomass was 
also removed from the experimental units every seven days, oven-dried to constant weight and then weighed $\left(\mathrm{gDM} . \mathrm{m}^{-2}\right)$. The dead material was not returned to the experimental units, and the weights obtained every seven days were summed. The live wet biomass was transformed to grams of dry mass $\left(\mathrm{gDM} . \mathrm{m}^{-2}\right)$ by a linear regression between dry mass (DM) and wet mass (WM) of plants that were not used in the experiment, but originated from the same population as the plants used in the experiment. The equation obtained was $\mathrm{DM}=0.92876+0.06299^{*} \mathrm{WM}(\mathrm{r}=0.99)$. Water and E. crassipes data were analyzed to verify normality and homoscedasticity using the D'Agostinho and Bartlett tests. Subsequently, repeated-measures ANOVA and, if required, a Tukey test were applied to identify significant differences $(P \leq 0.05)$ between the water quality variables $(\mathrm{pH}$, electrical conductivity and dissolved oxygen) and between the live biomass of $E$. crassipes in the four treatments $\left(0,0.5,1.5\right.$ and $\left.3.0 \mathrm{~L} . \mathrm{m}^{-2}\right)$ in different weeks (time). One-way ANOVA and, if required, a Tukey test were used to identify significant differences $(P \leq 0.05)$ between the $\mathrm{TP}$ and TKN concentrations in water of the four treatments at the end of the experiment.

\section{Results}

Repeated-measures ANOVA indicated effects of the oil dosage and time on the $\mathrm{pH}$, electrical conductivity and dissolved oxygen of the water (Table 1). The initial $\mathrm{pH}$ was equal in all experimental units, but on day 84 , the $\mathrm{pH}$ was significantly lower in the control $(4.46 \pm 0.35)$ and higher in the dosages of $1.5 \mathrm{~L} \cdot \mathrm{m}^{-2}(6.16 \pm 0.15)$ and $3.0 \mathrm{~L} . \mathrm{m}^{-2}(6.36 \pm 0.5)$. Electrical conductivity showed a significant increase between days 0 and 84 in all treatments. On day 84, electrical conductivity was significantly lower in the control $\left(0.077 \pm 0.009 \mathrm{mS} . \mathrm{cm}^{-1}\right)$ and higher in $3.0 \mathrm{~L} . \mathrm{m}^{-2}$ $\left(0.167 \pm 0.007 \mathrm{mS} . \mathrm{cm}^{-1}\right)$. Dissolved oxygen differed significantly between the treatments on day 0 . On this day, the value recorded for the control was $4.41 \pm 0.70 \mathrm{mg} . \mathrm{L}^{-1}$, and for $3.0 \mathrm{~L} \cdot \mathrm{m}^{-2}$ was only $0.70 \pm 0.26 \mathrm{mg}$. $\mathrm{L}^{-1}$. Subsequently, the concentrations of dissolved oxygen in $0.5,1.5$ and $3.0 \mathrm{~L} . \mathrm{m}^{-2}$ remained significantly lower than in the control until day 84 (Figure 1). The water temperature in the experimental units varied between 22.3 and $30.2^{\circ} \mathrm{C}$ during the experiment.

On the first day of the experiment in all treatments, the TKN and TP levels were $0.016 \pm 0.003 \mathrm{mg} . \mathrm{L}^{-1}$ and $45.3 \pm 8.1 \mu \mathrm{g} . \mathrm{L}^{-1}$, respectively. TKN did not differ significantly among the treatments at the end of the experiment (day 84) $(\mathrm{F}=0.97, \mathrm{P}>0.05)$. TP values were significantly different on day $84(\mathrm{~F}=18.21, \mathrm{P} \leq 0.05)$. The highest value was found in the dosage of $3 \mathrm{~L} \cdot \mathrm{m}^{-2}$ and the lowest in the control (Table 2). Repeated-measures ANOVA revealed effects of the oil dosage and time on the live biomass of E. crassipes (Table 3). The live biomass in the control treatment $\left(0 \mathrm{~L} \cdot \mathrm{m}^{-2}\right)$ increased significantly between day $0\left(39.8 \pm 3.0 \mathrm{gDM} . \mathrm{m}^{-2}\right)$ and day $84\left(70.5 \pm 7.1 \mathrm{gDM} \cdot \mathrm{m}^{-2}\right)$. At the

Table 1. Results of repeated-measures ANOVA applied to data for $\mathrm{pH}$, electrical conductivity and dissolved oxygen of water in the four oil-addition treatments $(0,0.5,1.5$ and $3 \mathrm{~L} \cdot \mathrm{m}^{-2}$ ) on different days (time), $\mathrm{df}=$ degrees of freedom and MS = mean square.

\begin{tabular}{lcrrc}
\hline & gl & \multicolumn{1}{c}{ MS } & \multicolumn{1}{c}{$\mathbf{F}$} & P \\
\hline $\mathbf{p H}$ & & & & \\
$\quad$ Treatment & 3 & 10.42 & 21.17 & 0.00038 \\
$\quad$ Time & 12 & 1.18 & 11.03 & 0.00001 \\
$\quad$ Treatment $\times$ Time & 36 & 0.57 & 5.37 & 0.00001 \\
Electrical conductivity & & & & \\
$\quad$ Treatment & 3 & 0.02 & 35.62 & 0.00005 \\
$\quad$ Time & 12 & 0.01 & 237.27 & 0.00001 \\
$\quad$ Treatment $\times$ Time & 36 & 0.01 & 11.17 & 0.00001 \\
Dissolved oxygen & & & & \\
$\quad$ Treatment & 3 & 120.35 & 107.73 & 0.00001 \\
$\quad$ Time & 10 & 1.06 & 6.72 & 0.00001 \\
$\quad$ Treatment $\times$ Time & 30 & 0.43 & 2.72 & 0.00020 \\
\hline
\end{tabular}

Table 2. Means and standard deviations $( \pm)$ of total Kjeldahl nitrogen (TKN) and total phosphorus (TP) of water in the four oil-addition treatments $(0,0.5$, 1.5 and $3 \mathrm{~L} \cdot \mathrm{m}^{-2}$ ) at the start (day 0 ) and end (day 84) of the experiment. Different letters indicate significant differences $(P \leq 0.05)$ between the treatments by Tukey test.

\begin{tabular}{ccc}
\hline Treatments & TKN $\left(\mathbf{m g} \cdot \mathrm{L}^{-1}\right)$ & TP $\left(\mu \mathrm{g} \cdot \mathrm{L}^{-1}\right)$ \\
\hline Beginning & $0.016 \pm 0.003^{\mathrm{a}}$ & $45.3 \pm 8.1^{\mathrm{b}}$ \\
0 L.m ${ }^{-2}$ & $0.011 \pm 0.001^{\mathrm{a}}$ & $21.3 \pm 1.4^{\mathrm{c}}$ \\
0.5 L.m $\mathrm{m}^{-2}$ & $0.012 \pm 0.004^{\mathrm{a}}$ & $35.9 \pm 22.7^{\mathrm{b}, \mathrm{c}}$ \\
1.5 L.m & $0.013 \pm 0.003^{\mathrm{a}}$ & $63.4 \pm 27.9^{\mathrm{a}, \mathrm{b}}$ \\
3.0 L.m $\mathrm{m}^{-2}$ & $0.017 \pm 0.007^{\mathrm{a}}$ & $133.5 \pm 11.8^{\mathrm{a}}$ \\
\hline
\end{tabular}

Table 3. Results of repeated-measures ANOVA applied to data for live biomass of Eichhornia crassipes in the four oil-addition treatments $\left(0,0.5,1.5\right.$ and $\left.3 \mathrm{~L} \cdot \mathrm{m}^{-2}\right)$ on different days (time).

\begin{tabular}{lcrrc}
\hline & gl & MS & F & P \\
\hline Live biomass & & & & \\
Treatment & 3 & 9082.80 & 18.69 & 0.00056 \\
Time & 12 & 463.10 & 12.33 & 0.00001 \\
Treatment $\times$ Time & 36 & 699.40 & 18.62 & 0.00001 \\
\hline
\end{tabular}



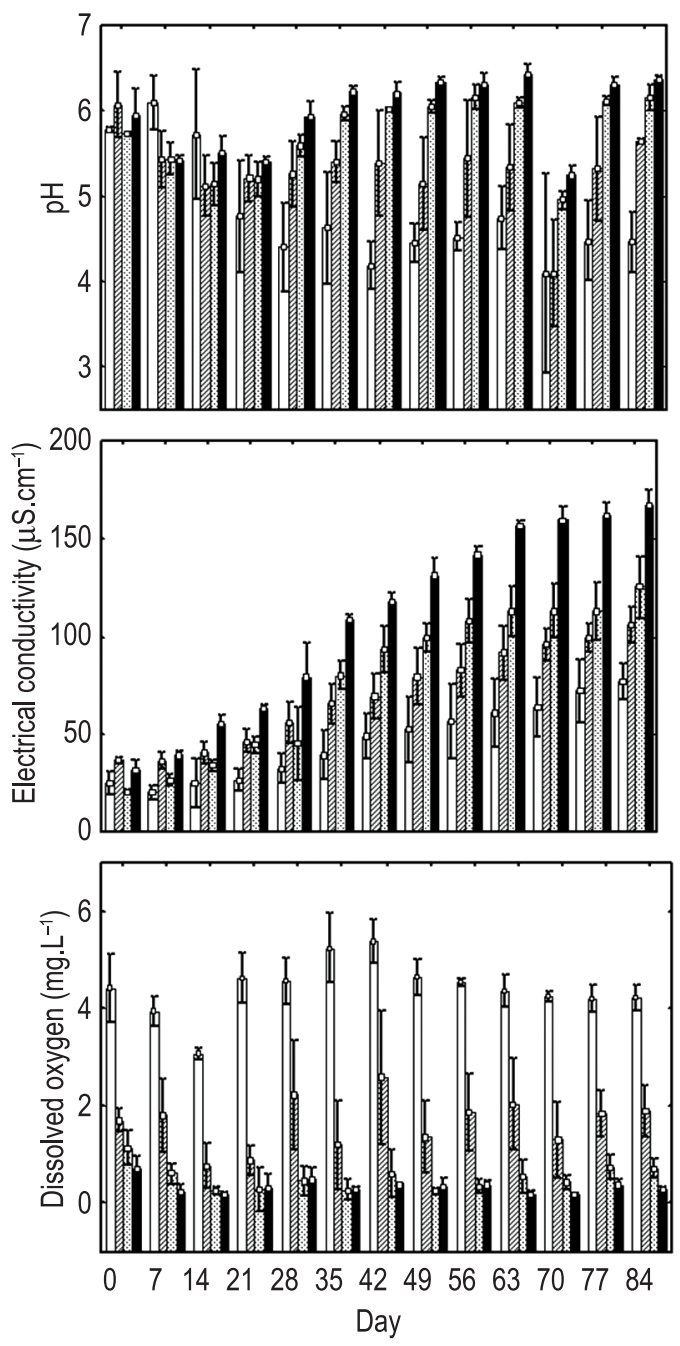

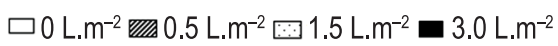

Figure 1. Means and standard deviations of $\mathrm{pH}$, electrical conductivity and dissolved oxygen of water in the four oil-addition treatments $\left(0,0.5,1.5\right.$ and $\left.3 \mathrm{~L} . \mathrm{m}^{-2}\right)$.

dosage of $0.5 \mathrm{~L} . \mathrm{m}^{-2}$ live biomass also increased significantly between day $0\left(39.8 \pm 3.0 \mathrm{gDM}^{-2}\right)$ and day $84\left(66.7 \pm 11.8\right.$ gDM.m $\left.{ }^{-2}\right)$. After day 35 , the live biomass in the $1.5 \mathrm{~L} \cdot \mathrm{m}^{-2}$ treatment was significantly less than in the control and reached $45.7 \pm 5.3$ gDM.m ${ }^{-2}$ on day 84 . For the $3.0 \mathrm{~L} . \mathrm{m}^{-2}$ dose, live biomass was significantly less than in the control after day 35, with total mortality at day $84\left(0 \mathrm{gDM} . \mathrm{m}^{-2}\right)$ (Figure 2$)$. For the dosage of $0.5 \mathrm{~L} \cdot \mathrm{m}^{-2}$, mortality began on day $35\left(7.5 \pm 2.7 \mathrm{gDM} . \mathrm{m}^{-2}\right)$ and on day 84 the dead biomass value was $21.1 \pm 6 \mathrm{gDM} . \mathrm{m}^{-2}$. For the 1.5 L.m $\mathrm{m}^{-2}$ and $3 \mathrm{~L} . \mathrm{m}^{-2}$ dosages, mortality began after day 21 , and on day 84 the dead biomass values were $30.5 \pm 11.1 \mathrm{gDM} . \mathrm{m}^{-2}$ and $70.0 \pm 11.1 \mathrm{gDM} \cdot \mathrm{m}^{-2}$, respectively. No mortality of $E$. crassipes occurred in the control treatment (Figure 2).

\section{Discussion}

The Urucu crude oil negatively affected the live biomass of E. crassipes. A dosage of $0.5 \mathrm{~L} \cdot \mathrm{m}^{-2}$ caused partial mortality, and $3.0 \mathrm{~L} . \mathrm{m}^{-2}$ caused total mortality in this species after 84 days exposure. E. crassipes showed lower sensitivity to Urucu crude oil than do other species of Amazon macrophytes. A dosage of $0.2 \mathrm{~L} \cdot \mathrm{m}^{-2}$ caused total mortality of the free-floating macrophyte Pistia stratiotes after 91 days of exposure (Silva and Camargo, 2007), and a dosage of $0.66 \mathrm{~L} . \mathrm{m}^{-2}$ caused total mortality of the aerial parts of the emergent macrophyte Echinochloa polystachya (H.B.K.) Hitchcock (Poaceae) within 21 days of exposure (Lopes et al., 2009). The smaller size and the haired leaf surface of $P$. stratiotes may partly explain the higher toxicity of oil to this species than to E. crassipes (Silva and Camargo, 2007). The characteristics of the leaf of $P$. stratiotes allow oil to be absorbed by the leaf surface. The presence of oil on the surface of the leaves impedes gas exchange, and this affects photosynthesis and plant growth (Pezeshki and DeLaune, 1993). Oil can also alter cell-membrane permeability, thus endangering plant metabolic processes (DeLaune et al., 2003). The lower sensitivity of E. crassipes to oil compared to that of E. polystachya may be due to the reduced contact that the root of the former species has with the oil. Only the soluble fraction of the oil dissolves into the water column, with the insoluble portion forming a film on the water surface (Val and Almeida-Val, 1999). This implies that the insoluble part of the oil is not in contact with the root system of E. crassipes, a floating macrophyte. By contrast, both oil fractions (insoluble and soluble) penetrate the soil and can quickly reach the root system of an emergent macrophyte fixed to the substrate, such as E. polystachya (Lopes and Piedade, 2011).

We found that exposure period was another important factor in determining the effect of Urucu crude oil on E. crassipes. At the dosage of $0.5 \mathrm{~L} . \mathrm{m}^{-2}$ the plant began to die only after 35 days of exposure, but most of the biomass remained alive. At a dosage of $3.0 \mathrm{~L} . \mathrm{m}^{-2}$, toxic effects were recorded within 21 days, and at the end of the experiment all the live biomass had disappeared. The length of exposure was also important in determining the effects of Urucu crude oil on E. polystachya, with a reduction in leaf size occurring after only 20 days of exposure (Lopes and Piedade, 2009). P. stratiotes showed mortality after seven days at dosages of 0.1 and 0.2 L.m ${ }^{-2}$ (Silva and Camargo, 2007). Therefore, both the concentration and the period of exposure 
(a)

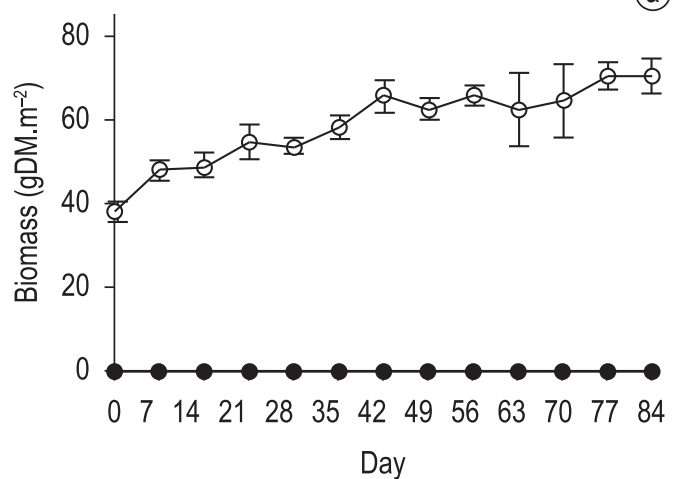

(b)

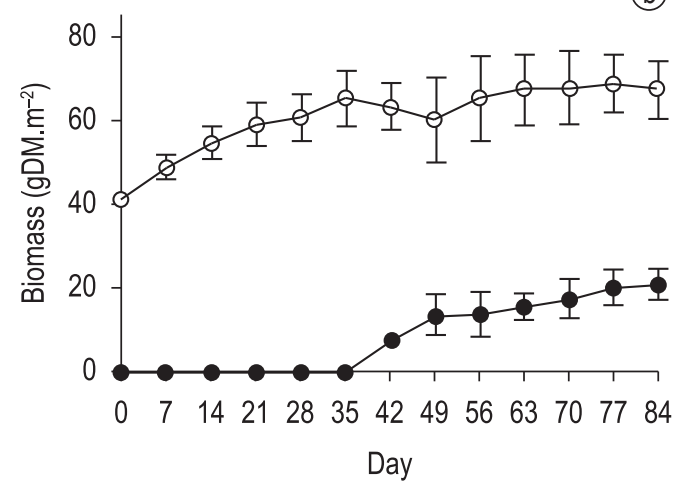

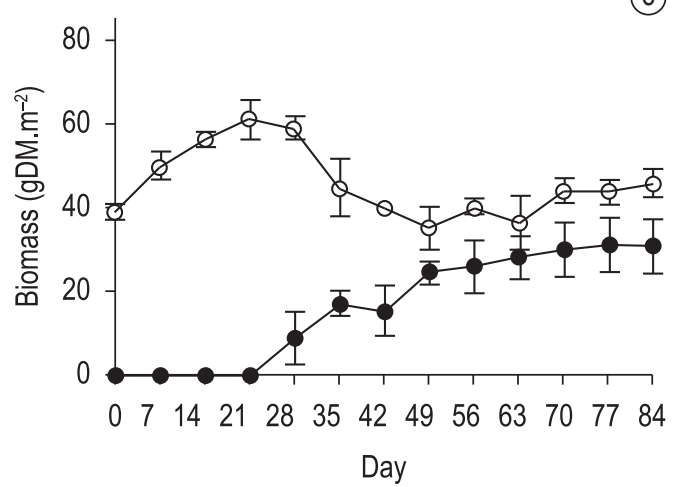

(d)



Figure 2. Means and standard deviations of live $(\circ)$ and dead $(\bullet)$ biomass of Eichhornia crassipes in the four oil addition treatments: 0 (a); 0.5 (b); 1.5 (c) and $3.0 \mathrm{~L} \cdot \mathrm{m}^{-2}$ (d).

to petroleum determine the intensity of the impact on $E$. crassipes and other aquatic macrophytes.

In addition to the effect of oil on this aquatic macrophyte, we observed changes in some abiotic characteristics of the water, especially in the treatment with the highest volume of oil. The decomposition of the oil and the dead biomass of $E$. crassipes reduced the dissolved oxygen and $\mathrm{pH}$, and increased electrical conductivity and concentrations of total phosphorus in the water. A small reduction in oxygen concentration was also observed by Silva and Camargo (2007). The intensity of changes in the characteristics of the water is influenced by several factors, including the concentrations of oil and dead plant biomass. In this study, the amounts of oil used and the dead biomass of the plant were larger than in the study of Silva and Camargo (2007). However, despite the intensity, these changes may have consequences for other organisms than the aquatic macrophytes.

We conclude that an oil spill can cause total mortality in the local population of one macrophyte species, but not of another. This may alter the macrophyte species diversity in the impacted region. In the case of $E$. crassipes and $P$. stratiotes, an Urucu crude oil spill could favor $E$. crassipes, the less sensitive species.

\section{Acknowledgements}

The authors thank Technician Carlos Fernando Sanches for help with the execution of the experiment and the laboratory analysis. The first author received a scholarship grant from Agência Nacional do Petróleo (PRH-05/Rio Claro).

\section{References}

AGAMI, M. and REDDY, KR. 1990. Competition for space between Eichhornia crassipes (Mart.) Solms and Pistia stratiotes $\mathrm{L}$. culture in nutrient-enriched water. Aquatic Botany, vol. 38, no. 2-3, p. 195-208. http:// dx.doi.org/10.1016/0304-3770(90)90005-6

DELAUNE, RD., PEZESHKI, SR., JUGSUJINDA, A. and LINDAU, CW. 2003. Sensitivity of US Gulf of Mexico coastal marsh vegetation to crude oil: Comparison of greenhouse and field responses. Aquatic Ecology, vol. 37, no. 4, p. 351-360. http://dx.doi. org/10.1023/B:AECO.0000007047.42636.96

GOLTERMAN, HL., CLYMO, RS. and OHNSTAD, MAM. 1978. Methods for chemical analysis of fresh waters. Oxford: Blackwell Scientific. 213 p.

LIN, Q. and MENDELSSOHN, IA. 1996. A comparative investigation of the effects of south Louisiana crude oil on vegetation of fresh, brackish and salt marshes. Marine Pollution Bulletin, vol. 32, no. 2, p. 202-209. http://dx.doi.org/10.1016/0025-326X(95)00118-7 
LOPES, A. and PIEDADE, MTF. 2009. Estabelecimento de Echinochloa polystachya (H.B.K.) Hitchcock (Poaceae) em solo de várzea contaminado com petróleo de Urucu. Acta Amazonica, vol. 39, no. 3, p. 583-590. http://dx.doi.org/10.1590/S004459672009000300013

LOPES, A. and PIEDADE, MTF. 2011. Time of exposure and oil dosage affecting biomass production of the Amazonian semi-aquatic grass Echinochloa polystachya. Rodriguesia, vol. 62, no. 4, p. 901-908.

LOPES, A., ROSA-OSMAN, SM. and PIEDADE, MTF. 2009. Effects of crude oil on survival, morphology, and anatomy of two aquatic macrophytes from the Amazon floodplains. Hydrobiologia, vol. 639, no. 1, p. 295-305. http://dx.doi.org/10.1007/ s10750-009-9959-6

MACKERETH, FIF., HERON, J. and TALLING, JF. 1978. Water analysis: some revised methods for limnologists. London. 120 p. Freshwater Biological Association Scientific Publication, no. 36.

Petrobrás. 2010. Provincia petrolifera de Urucu. Available from: <http://www2.petrobras.com.br/minisite/ urucu/urucu.html>. Access in: 05 nov. 2010.

PEZESHKI, SR. and DELAUNE, RD. 1993. Effect of crude oil on gas exchange functions of Juncus roemerianus and Spartina alterniflora. Water, Air, and Soil Pollution, vol. 68, no. 3-4, p. 461-468. http:// dx.doi.org/10.1007/BF00478469

PEZESHKI, SR., JUGSUJINDA, A. and DELAUNE, RD. 1998. Responses of selected U.S. Gulf Coast marsh macrophyte species to oiling and commercial cleaners. Water, Air, and Soil Pollution, vol. 107, no. 1-4, p. 185-195.

SILVA, RS. and CAMARGO, A.F.M. 2007. Effect of Urucu crude oil on the aquatic macrophyte Pistia stratiotes. Acta Limnologica Brasiliensia, vol. 19, no. 2, p. 155-161.

STEPANYAN, OV. and VOSKOBOINIKOV, GM. 2006. Effect of oil and oil products on morphofunctional parameters of marine macrophytes. Russian Journal of Marine Biology, vol. 32, no. 1, p. 32-39. http:// dx.doi.org/10.1134/S1063074006070042

TUNDISI, JG. and MATSUMURA-TUNDISI, T. 2008. Limnologia. São Paulo: Oficina de Textos. 632 p.

VAL, AL. and ALMEIDA-VAL, VMF., 1999. Effects of crude oil on respiratory aspects of some fish species of the Amazon. In VAL, AL. and ALMEIDA-VAL, VMF., eds. Biology of Tropical Fishes. Manaus: INPA. 460 p.

VILLAMAGNA, AM. and MURPHY, BR. 2010. Ecological and socio-economic impacts of invasive water hyacinth (Eichhornia crassipes): a review. Freshwater Biology, vol. 55, no. 2, p. 282-298. http:// dx.doi.org/10.1111/j.1365-2427.2009.02294.x

WERNICK, BG., DEBRUYN, AMH., PATTERSON, L. and CHAPMAN, PM. 2009. Effects of an oil spill on the regrowth of emergent vegetation in a northern Alberta Lake. Archives of Environmental Contamination and Toxicology, vol. 57, no. 4, p. 697-706. PMid:19333646. http://dx.doi. org/10.1007/s00244-009-9311-1

Received: 28 October 2011 Accepted: 04 May 2012 